\title{
Legal Issues of Developing Countries in the WTO Dispute Settlement System
}

\author{
Amirbekova Alua Sharipbekkyzy \\ PhD student, Al-Farabi Kazakh National University, 71 al-Farabi Ave., Almaty, Republic of Kazakhstan, 050038
}

\author{
Doi:10.5901/mjss.2015.v6n5p50
}

\begin{abstract}
This paper studies the issues on standing up for national interests of developing countries in the - WTO dispute settlement system. The current rules setting forth the general procedure of dispute settlement within the WTO were considered with that procedure's specifics in connection with developing countries, the experiences of a few countries were studied, the analysis was made in connection with the prospects of new WTO members' adaptation to the real conditions of the dispute settlement process. The author opines that a successful pledge for such adaptation is the establishment of specialized governmental authorities with exclusive powers in connection with the WTO, improvement of their staff professionalism, establishment of connections with the private sector capable to influence the foreign trade policy, calling for private lawyers' services.
\end{abstract}

Keywords: Developing countries, WTO members, dispute settlement mechanism, dispute experience.

\section{Introduction}

International agreements executed within the WTO (World Trade Organization) govern a wide range of international relations including customs tariffs and their application procedure, foreign currency balance measures, technical requirements and standards applicable to goods and services, sanitary measures, governmental procurement, subsidies to participants of the international trade turnover. That mode of operation is ensured, besides all, by own system for settlement of disputes between member countries. This system is rather effective which is confirmed by the fact of many appeals lodged by WTO member countries; as on the beginning of 2013, 465 cases were brought in connection with the settlement of disputes (DSB Annual Report 2013).

The issue of growing disputes within the WTO, in particular concerning developing countries being WTO members is surely relevant for a number of countries created in the post-Soviet area, both from the national industry's protection point of view and from the point of view of own actions protection in connection with goods and services regulation. Entering the international club guaranteeing undiscriminated access to the markets of its members, new WTO members must be ready for active protection of their interests with applicable WTO dispute settlement mechanism.

In the future, new WTO members might be a party of a dispute, therefore, the study of developing countries' experience is a necessary condition for the protection of national economic and other interests under the WTO mechanism. In the international economic law, the issue of WTO dispute settlement was considered by many researchers from developed countries, including D. Carro and P. Juilliard, G. Shaffer, M. Ash. Among the Russian-speaking researchers, detailed study of that issue was made by V. Delich, S.L. Lapin, V.M. Shumilov. The level of knowledge of the dispute settlement procedure in the WTO is still rather low in the international trade law science of the post-Soviet countries, which may be due to their absence in the Organization for trade cooperation. However, as the process of their joining the WTO began, the relevance grew for the development of legal positions regarding the rules and the whole dispute settlement mechanism in general. New member countries need to take into account the possibility of disputes and foresee the ways to settle them within the WTO in trade policy implementation.

The methodology of this research comprises mainly basic research methods like: description, comparison, analysis, synthesis, analogy. The use of statistical method in the research of dispute experience of some most active developing countries like Brazil, Argentine, China will allow ascertaining the specifics of realization of the mechanism in practice by developing countries in WTO disputes.

\section{Results of Research}

First, let us see the parties of the WTO dispute settlement procedure. The WTO does not have own court: formally, disputes are considered and settled by the Dispute Settlement Body (DSB). In essence, the DSB is a political body 
comprising the representatives of all WTO members. Meantime, in practice, disputes are settled either by a panel or the Appellate Body, where the party which did not agree with panel's resolution may appeal against it. Meantime, if a panel consisting of three members is established separately for each dispute, appeal is considered by three members of continuously functioning the Appellate Body (total number of members is seven). Upon the results of the consideration, panel adopts a report containing either a conclusion on the absence of violation or a conclusion on the fact of violation and a recommendation to make the regulations or the behavior of state compliant with the liabilities under the WTO (Shumilov, 2003). Report by a panel (or the Appellate Body, if a panel's resolution was successfully appealed against) and recommendations contained therein are approved almost automatically: to disapprove them, a consensus of all DSB members is required which, in a situation when one of DSB members is the winning party is rather low probable and has virtually never been in practice (Bacchus, 2004).

Only states - WTO members may be parties of a dispute within the WTO. At first sight, it creates a paradox situation in which the entities mostly interested in fulfillment of liabilities provided for by WTO agreements - exporters of goods and services - are moved away from the mechanism for the control of their observance. However, in practice the private sector's role in the WTO disputes settlement system is rather more significant than it may seem. In most of developed countries exporters are successfully cooperating with governmental authorities: calling their attention to possible violations, ensuring the research confirming any unreasonableness of importer state's measures, sometimes participating in establishment and submission of state's position in the course of dispute consideration by a panel and the Appellate Body (Shaffer, 2007). The legislature of a few countries directly grants individuals the right to apply to a respective governmental authority with a request on initiation of proceedings in the WTO in the event of obligations violation by any other state (Usoskin, 2012).

The core document governing the DSB's operation - the Understanding on Rules and Procedures Governing the Settlement of Disputes (DSU) was developed during the Uruguay Round (Marrakesh Agreement Establishing the World Trade Organization dated April 15, 1994).

Coming to the study of developing countries' participation in the WTO dispute settlement, it should be stressed that Organization's official documents do not contain the term developing country. At first sight it may seem a problem, as member states of the developing category possess some preferences under WTO contracts. For example, they are granted longer periods for contracts implementation, they are entitled to obtain technical assistance in connection therewith and other support of their activities under the WTO (Abbot, 2007). In practice, member countries declare their development categories themselves, and despite that such self-determination may be argued by other countries, there have been no discrepancies in connection with that. In general the list of developing countries - members of the WTO matches the list of countries in the UN annual reports prepared upon the calculation of the Human Development Index.

The DSU contains a number of special rules regarding developing countries and least developed countries providing for special powers in the participation of disputes settlement mechanism. Those rules reflect the principle of special and differential treatment of developing and least developed countries. Such provisions being the consequence of that principle's application are contained in all trade agreements of the WTO and include the rights comparatively wider than those of developed countries. A good example of the above principle is clause 10 of article 8 governing the procedure for panels establishment: When a dispute is between a developing country Member and a developed country Member the panel shall, if the developing country Member so requests, include at least one panelist from a developing country Member. Article 4.10 provides that WTO members should give special attention to the particular problems and interests of developing country members and Article 12.10 provides for the extension of consultations period involving a measure taken by a developing country member if parties agree. Article 8.10 states that a developing country involved in a dispute may require to include at least one panelist from a developing country member in the panel, while Article 12.11 states that in such cases the panel's report shall explicitly indicate the form in which account has been taken of relevant WTO provisions on differential and more-favorable treatment for developing country members (Delich, 2003).

In the event if a case is brought by any developing country, the DSB in considering what appropriate action might be taken, shall take into account not only the trade coverage of measures complained of, but also their impact on the economy of developing country members concerned (Article 21.8 of the DSU). Article 27.2 provides for additional legal advice and assistance (technical support) in respect of dispute settlement to developing country members by the WTO Secretariat.

Special rules in the DSU are also granted for least developed country members. Article 24 Special Procedures Involving Least-Developed Country Members provides for the obligation of developed countries to exercise due restraint in raising matters under dispute settlement procedures involving a least-developed country member and possibly offer their good offices, conciliation and Director-General's mediation. Such recommendations in connection with developing countries' trade with least developed are mainly connected with the fact that participation in dispute settlement for least 
developed countries is hard because of various costs, and they are unable to productively stand for their interests in disputes within the WTO.

The above regulations contained in the DSU do not seem to carry any material consequences when applied in practice under the dispute settlement mechanism but are directly related to the research topic as the DSU provides for special rules for developing and least developed countries.

The study of some countries' experience begins with Brazil and Argentine as the oldest participants of dispute settlement within the WTO.

It is noted that Latin America and Asia are the regions of developing countries which are mostly involved in trade dispute settlement. So far no African country has brought any case and no case has been brought against them. However, a few African countries including Nigeria and Zimbabwe participated as third parties in proceedings on trade cases (Delich, 2003).

Brazil is one of the most successful users of the WTO dispute settlement system, among both developed and developing countries, and besides it should be stressed that it was the most frequent user of the DSU rules after the USA, the EU and Canada. Also, it is notable that Brazil won economically and strategically important disputes with the USA and the EU in agricultural sector (Barall, 2007). The success in the said proceedings became well-known, called public attention in Brazil, mobilized the government to get actively involved in Doha Round where it became the negotiations leader on behalf of developing countries. Currently Brazil together with India is a successful example of WTO membership for countries with average economic performance.

Such a success was achieved greatly due to the transformations occurred in the country's governmental authorities responsible for international trade, calling mass media to highlight foreign policy issues, public organizations, stimulation of private legal and consulting companies to invest in new spheres.

Upon involvement in the WTO dispute settlement mechanism, the government developed so-called three pillar system named by Ministry of foreign affairs of Brazil. It comprises specialized department for participation in WTO disputes in Itamaraty (the first pillar), coordination of that department with Geneva mission (the second pillar) and cooperation of both authorities with private organizations specialized in international law and consulting (the third pillar). As a part of the third pillar, Geneva mission arranged master's degree programs for staff of legal companies and state officials of Brazil (Merrills, 2005). But even the three pillar system may not account for the whole success that put Brazil in the lead among developing member countries of the WTO. As stated by a representative of Brazilian mission in Geneva, engaged in master program: "We are trying to distribute knowledge to create a critical mass of qualified staff" (Oesch, 2003). That statement may serve as a keynote to describe the specifics of building policy in connection with the dispute settlement mechanism and the WTO in general. The need for trade analysis of a state in connection with the WTO gave a start to the development of knowledge and new domestic labor market.

Now we will examine in detail the changes occurred in Brazil's authorities responsible for the work within the WTO.

Brazil established a professional department capable to contribute to the achievement of its objectives in WTO disputes, under Ministry of foreign affairs; besides that, full-time units were established in other ministries with the tasks of trade expertise and analysis. Before 2001, only one department in Ministry of foreign affairs was responsible for external trade connections with the WTO, MERCOSUR, FTAA and ALADI. As a result of further restructuring of Ministry of foreign affairs, six specialized offices were created inside the Ministry. One was General department for dispute settlement consisting of 5-6 specialists in that field. The department became liable for the analysis of legal and factual reasons for complaints brought to the DSB, preparation of legal documents, representation on panel hearings. The authority is cooperating with the business areas and trade associations concerned, standing for the protection of private sector's interests in international disputes.

An integral part of the three pillar system in Brazil is to call for attention to international trade disputes from nongovernmental organizations, private legal and consulting companies, science, mass media. Thus, the state was supported by public in the exercising of its trade.

As a result of growing overall interest to the country's activity in the WTO, national legal companies opened a new market of services. The competition between specialized lawyers in international commercial law sector grew to the levels incomparable to those in other developing countries. The work of Brazilian legal company Veirano \& Advogados which followed all the procedure of dispute settlement with the EU - Customs classifications of poultry, and with Argentine on a similar matter evidences high qualification of lawyers.

Summarizing the experience of Brazil in dispute settlement within the WTO, a few conclusions should be made. First of all, we stress that Brazil is a telling example for developing countries as a successful member of the WTO. Also, it should be noted that the involvement in international trade caused the required transformations in the machine of state ensuring strengthening country's position in the WTO. Being a defendant in strategically important disputes, Brazil 
mobilized its efforts for the successful settlement of disputes. Thus, one of the conditions required for fruitful participation in the dispute settlement mechanism may be the cooperation between government and private sector.

Argentine's experience. Engaged in two cases simultaneously, Argentine did not have time and enough experience to call for third party specialists and it became clear that disputes will be followed by governmental authorities. By the moment when the USA called for panel to consider the case on measures in connection with textile and shoes import in 1997, Argentine's government was not restructured in compliance with new legal procedures on the dispute settlement within the WTO. For example, the governmental machine did not have a body responsible for trade disputes. Those obligations were imposed on Directorate of international economic relations subordinate to Ministry of foreign affairs. Participation in disputes within the GATT was limited to establishment of groups ad-hoc but in that situation it was not a possible solution of the problem for Argentine. Cases against the USA and the EU urged the government to make changes to establish a specialized body representing interests in WTO disputes. By August 2000, the internal restructuring of Ministry of foreign affairs and international trade of Argentine was completed. As a result, the new agency called Directorate for settlement of international economic disputes (DISCO) was established. The functions of the new agency were as follows:

1. To represent Argentine in disputes within the WTO.

2. To collect and analyze disputes database between WTO members.

3. To render assistance in developing positions on trade negotiations.

4. To prevent political steps potentially leading to conflicts.

Table of organization of the new agency initially included three diplomats and one lawyer. By the moment when Argentine was on the peak of its participation in the WTO dispute settlement mechanism, the directorate included 10 persons: director (diplomat/lawyer), deputy director (diplomat/economist), middle rank diplomat (economist), 4 assistant diplomats ( 1 foreign trade specialist and 3 lawyers), 2 lawyers working under contract and 1 technical assistant (Shaffer, 2010).

Argentine's experience in disputes within the WTO should be assessed as the result of two parameters: reasonable and comprehensive exercising of trade policy and concentration of resources for each separate dispute within the WTO.

It seems that despite the establishment of a special governmental authority responsible for representing Argentine in international disputes, the activity under the dispute settlement mechanism may be called unsystematic or chaotic. Such a conclusion may be made based on some statistical data. Out of the ten disputes Argentine was involved in 2005 2012, legal companies were called in four cases, in the remaining cases the work was done by the Directorate only, in five cases the level of inter-agency cooperation was declared high compared to the remaining five, and only in three cases expertise was used by Argentine's petition (Shaffer, 2010).

The practice of participation in those proceedings called for the need to build a wider structure in connection with office administration within the WTO.

For example, a core element to determine the reasonability of a trade dispute could be a uniform system with the information database including private sector interests, economy's needs, legal instruments and calculation of costs. For the functioning of such a system, the legal basis is required to govern the procedure for participation of private sector in making foreign trade policy. For example, the list of reasons required for legitimate claiming from the government the involvement in a potential dispute by certain international trade market players. Training specialists also plays an important part as an integral aspect of that system.

China's experience of WTO membership seems the most valuable for this research as it is a country, which entered the Organization quite recently not being GATT member. Touched by the need to exercise trade under the new legal system, China faced a number of problems.

The lack of experience of using WTO rules by Chinese legal companies and in general the lack of specialists competent in general law both in governmental bodies and in private sector was an argument against the new WTO member. To overcome the said faults, country's leaders undertook a number of steps causing material changes in the structure of governmental bodies aimed at ensuring effective membership of China in the WTO.

In March 2003 Ministry of trade and economic cooperation (MOFTEC) was restructured into Ministry of commerce (MOFCOM), and it comprised Department of WTO relations, while WTO section was established in Department of contracts and law directly engaged in dispute settlement. Minister of commerce could upon prime minister's approval bring a case on behalf of the PRC to the WTO DSB. With such a structure, coordination issue between various ministries and government remains in connection with the matters of the policy exercised within the WTO. For example, back in 2006, to assess antidumping measures, the cooperation of customs bodies, Ministry of commerce and State commissions on economy and trade was needed. Such cooperation interfered in successful exercising of tasks. 
Difficulties in the coordination of actions regarding disputes within the WTO do exist between authorities and private sector despite that many of them have a management stake on behalf of the government.

A brief review of cases in which the PRC was the defendant shows that the key problem segments of trade within the WTO were the mineral export, intellectual property rights, value added tax and profit, customs rules. In $70 \%$ of cases brought against China the final resolution was made by the DSB against China. Obviously, the reason for such unsuccessful participation of China in the dispute settlement mechanism was the incompliance of domestic law with the Organization's rules and the absence of uniform trade policy meeting the requirements of WTO agreements under a single special body.

Surely, some other factors are of concern, for example, like the absence of accumulated database of WTO rules application, as China has been a recent member, as well as the lack of specialists in state bodies and private companies. Naturally, the PRC has been integrating into the system of WTO regulations and has been adopting certain measures in connection therewith. Among them the following may be specified:

1. training programs in WTO law for state officials funded by the government;

2. special courses in WTO law in universities and development of academic science in that direction;

3. establishment of administrative consulting and legal centers in connection with the WTO in various Chinese cities (Shanghai, Beijing, Shenzhen), exercising consulting, training and research activities in WTO law (Shaffer, 2010).

Based on the comprehensive analysis of application of the dispute settlement mechanism within the WTO by China it seems that the PRC as a member is still integrating in the Organization's system. At this moment, the country has all the prospects for successful activity within the Organization in future. They include growing experience of applying the DSU, improved cooperation of state authorities responsible for relations with the WTO, training specialists in that area and regulations restructuring in compliance with the WTO law.

\section{Discussion}

Each of the countries considered had its own specifics of participation in dispute settlement mechanism, but if general trends are outlined, a few conclusions may be made. The terms and conditions of the DSU in connection with special and differential treatment of developing countries in WTO agreements are not effective, as developing countries do not receive potential benefit from neutrality of the international trade. Although the DSU is not against any party of a trade dispute, developing countries are less equipped for attending the proceedings: they have less qualified specialists with respective education, they are less experienced and they possess less financial resources (Horn, 1999).

Thus, full use of the WTO dispute settlement mechanism for developing countries is not quite available in practice yet so far due to a number of reasons.

So, the practice of protecting interests by least developed countries has not been obtained yet. Further success in disputes is hindered by unavailability of a number of organizational and legal resources including the absence of specialized governmental authorities with significant powers regarding the WTO and specially trained international lawyers (Sharikhodzhaev, 2005). The literature specifies one more important reason explaining the problem of the dispute settlement mechanism by developing countries, namely the lack of professionalism of full-time governmental officials compared to those from the USA or elsewhere (Lapin, 2007).

\section{Conclusion}

The experience of Brazil and China shows that defending in the WTO disputes may mobilize the governments to act for successful solution of own interests protection tasks in future. It should be noted that attending cases as a third party may improve the experience and establish good practice basis for the countries being novices in the dispute settlement mechanism. Development of the academic science, creation of new service markets in connection with the WTO regulations for consulting and legal companies, mass media attention to the issues of national trade policy as integral prerequisites for fruitful activity should be ensured by the countries planning to successfully use the WTO system.

Developing countries should undertake to obtain external funding for training, advanced training, improvement of opportunities, as well as establishment of collective mechanism of developing countries to monitor the trade policies of developed countries in respective sectors and spheres of concern for the developing countries in question. Such collective monitoring mechanism is required not only for cutting the costs of developing countries on monitoring the trade policies of developed countries but also for coordination of efforts on bringing collective cases. Besides, developing countries may use the proceedings in connection with trade disputes which they are parties of to find any defects in WTO agreements which may be eliminated by negotiation. 


\section{References}

WTO Dispute Settlement Body Annual Report (2014).

Shumilov, V. (2003). WTO's law and antidumping proceedings under Russian law. Zakon, 4.

Bacchus, J. (2004). Lone Star: The Historic Role of the WTO. Texas International Law Journal, 37, 408.

Shaffer, G. (2007). 'Public-Private Partnerships' in WTO Dispute Settlement: the US and EU Experience. The WTO in the Twenty-First Century: Dispute Settlement, Negotiations, and Regionalism in Asia. Cambridge University Press.

Usoskin, S. (2012). Mechanism for settlement of disputed within World Trade Organization: brief highlights. International justice, 1, 6977.

Abbot, R. (2007). Are developing countries deterred from using the WTO Dispute Settlement System? ECIPE Working Paper, No. $01 / 2007$

Understanding on rules and procedures governing the settlement of disputes. (n.d.). Retrieved March 17, 2015, from http://docs.pravo. ru/document/view/18484490/16156366.

Delich, V. (2003). WTO Guideline: Trade, development and WTO. Chapter 9 Developing countries and WTO's dispute settlement system.

Barral, W. (2007). The Brazilian experience in Dispute Settlement. UN Economic Commission for Latin America and the Caribbean, UN Doc. LC/W.147.

Merrills, J. (2005, October 27). International Dispute Settlement. Cambridge University Press.

Oesch, M. (2003). Standards of Review in WTO Dispute Resolution. Oxford Press.

Shaffer, G., \& Melendez-Ortiz, R. (2010). Dispute Settlement at the WTP. The developing country experience. Cambridge University Press.

Horn, H., Nordström, H., \& Mavroidis, P. (1999). Is the use of the WTO dispute settlement system biased? CEPR Discussion Paper Series, No. 2340.

Shadikhodzhaev, S. (2005). Application and restructuring of current system for settlement of disputes within WTO. Moscow journal of international law, 3, 198.

Lapin, S. (2007). Some issues of dispute settlements system within WTO. State and law, 9, 105. 